\title{
Correction to: Extending the straight leg raise test for improved clinical evaluation of sciatica: validity and diagnostic performance with reference to the magnetic resonance imaging
}

Janne Pesonen ${ }^{1,2^{*}}$, Michael Shacklock ${ }^{1,3}$, Juha-Sampo Suomalainen ${ }^{4}$, Lauri Karttunen ${ }^{1,2}$, Jussi Mäki ${ }^{1}$, Olavi Airaksinen ${ }^{1,2}$ and Marinko Rade 1,5,6

Correction to: BMC Musculoskelet Disord 22, 808 (2021)

https://doi.org/10.1186/s12891-021-04649-z

Following publication of the original article [1], the authors reported an error that Table 2 is missing from the publication.

The missing Table 2 is shown below. The original article [1] has been updated.

Table 2 Cohen's Kappa values for agreement between the MRI findings and ESLR or traditional SLR results

\begin{tabular}{llll}
\hline & Kappa & $\mathbf{9 5 \% C l}$ & $\boldsymbol{p}$-value \\
\hline ESLR / LDH on MRI & 0.30 & $0.03-0.57$ & 0.04 \\
ESLR / NC on MRI & 0.25 & $-0.04-0.54$ & 0.10 \\
Trad. SLR / LDH on MRI & 0.17 & $-0.01-0.35$ & 0.11 \\
Trad. SLR / LDH on MRI & 0.07 & $-0.16-0.29$ & 0.57
\end{tabular}

ESLR Extended straight leg raise test, $L D H$ Lumbar disc herniation, MRI Magnetic resonance imaging, NC Neural root compression, Trad. SLR Traditional straight leg raise test, $95 \% \mathrm{Cl} 95 \%$ confidence interval

\begin{abstract}
Author details
${ }^{1}$ Department of Rehabilitation, Kuopio University Hospital, PL 100, 70029 KYS, Kuopio, Finland. ${ }^{2}$ Department of Surgery (incl. Physiatry), University of Eastern Finland, Kuopio, Finland. ${ }^{3}$ Neurodynamic Solutions, Adelaide, Australia. ${ }^{4}$ Department of Clinical Radiology, Kuopio University Hospital, Kuopio, Finland. ${ }^{5}$ Faculty of Medicine, University of Osijek, Orthopaedic and Rehabilitation Hospital "Martin Horvat", Rovinj, Croatia. ${ }^{6}$ Department of Natural and Health Studies, Juraj Dobrila University of Pula, Pula, Croatia.
\end{abstract}

Published online: 10 November 2021

\section{Reference}

1. Pesonen J, Shacklock M, Suomalainen JS, et al. Extending the straight leg raise test for improved clinical evaluation of sciatica: validity and diagnostic performance with reference to the magnetic resonance imaging. BMC Musculoskelet Disord. 2021;22:808. https://doi.org/10.1186/ s12891-021-04649-z.

The original article can be found online at https://doi.org/10.1186/s12891021-04649-z

*Correspondence: janne.pesonen@kuh.fi

2 Department of Surgery (incl. Physiatry), University of Eastern Finland, Kuopio, Finland

Full list of author information is available at the end of the article

(c) The Author(s) 2021. Open Access This article is licensed under a Creative Commons Attribution 4.0 International License, which permits use, sharing, adaptation, distribution and reproduction in any medium or format, as long as you give appropriate credit to the original author(s) and the source, provide a link to the Creative Commons licence, and indicate if changes were made. The images or other third party material in this article are included in the article's Creative Commons licence, unless indicated otherwise in a credit line to the material. If material is not included in the article's Creative Commons licence and your intended use is not permitted by statutory regulation or exceeds the permitted use, you will need to obtain permission directly from the copyright holder. To view a copy of this licence, visit http://creativecommons.org/licenses/by/4.0/. The Creative Commons Public Domain Dedication waiver (http://creativeco mmons.org/publicdomain/zero/1.0/) applies to the data made available in this article, unless otherwise stated in a credit line to the data. 